\title{
Hammond, Noufi, Roozeboom, and Trolier-McKinstry to Chair 2003 MRS Fall Meeting
}

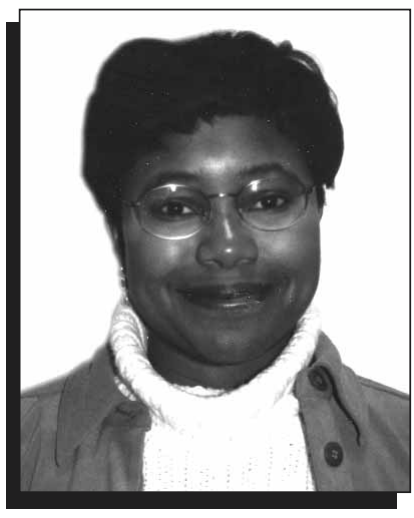

Paula Hammond

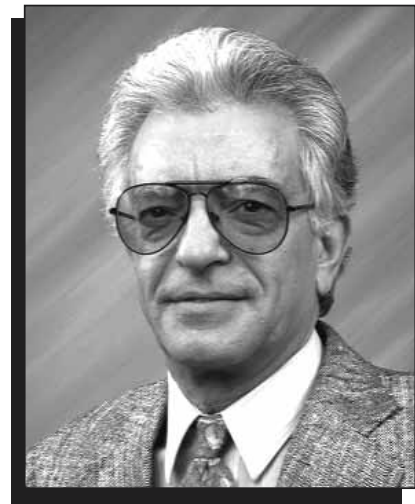

Rommel Noufi

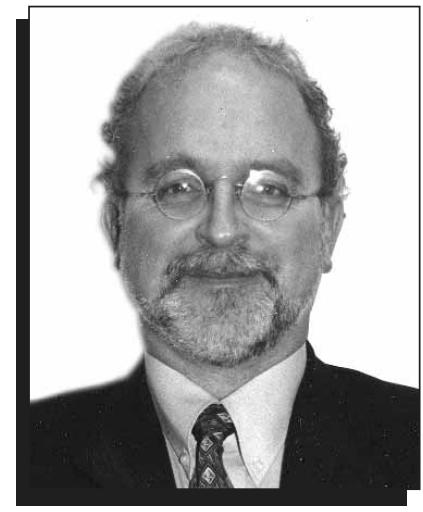

Fred Roozeboom

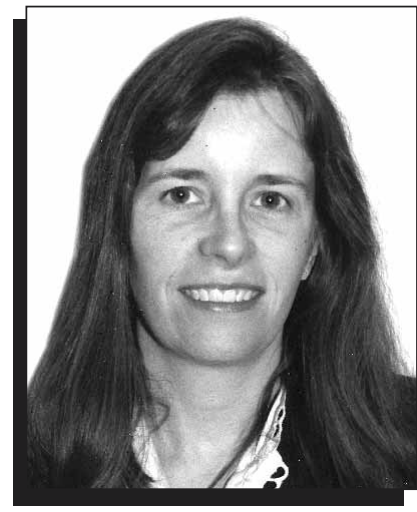

Susan Trolier-McKinstry
The 2003 Materials Research Society Fall Meeting in Boston on December 1-5 will be chaired by Paula Hammond (Massachusetts Institute of Technology), Rommel Noufi (National Renewable Energy Laboratory), Fred Roozeboom (Philips Research), and Susan Trolier-McKinstry (The Pennsylvania State University). For updated information on the Meeting, access URL www.mrs.org/meetings/.

Paula Hammond is an associate professor in chemical engineering at the Massachusetts Institute of Technology (MIT). She earned her SB degree (1984) in chemical engineering from the Massachusetts Institute of Technology, her MS degree (1988) from Georgia Institute of Technology, and her PhD degree (1993) in chemical engineering from MIT. In 1994, Hammond was awarded the NSF Postdoctoral Fellowship in Chemistry while performing postdoctoral research in the Harvard University Chemistry Department as a member of the Whitesides group. In 2000, Hammond was awarded the Junior Bose Faculty Award, and the GenCorp Signature University Award. She has also received the NSF Career Award (1997), the EPA Early Career Award (1996), the DuPont Young Faculty Award (1996), and 3M Innovation Fund Award (1995), and is on the Advisory Board of Advanced Materials and Chemistry of Materials. Her general areas of interest include electrical and optical properties of polymers and nano- to microscale fabrication using directed and self-assembly of polymers. Hammond has over 40 publications.

Rommel Noufi is a principal scientist at the National Renewable Energy Laboratory (NREL), leading activities in polycrystalline thin-film compound semiconductors for photovoltaic application. Noufi has estab- lished a leading position in the interdisciplinary fields of thin-film photovoltaic devices, materials science of chalcogenide materials, solid-state physics, vacuum technology, and photoelectrochemistry. He received his $\mathrm{PhD}$ degree in analytical/ physical chemistry from the University of Texas at Austin in 1978. Subsequently, he became a member of the technical staff at the Rockwell International Science Center in Thousand Oaks, California, working on thin-film growth and characterization of II-VI materials for photoelectrochemical cells. In 1980, he was recruited by the Solar Energy Research Institute (SERI), now NREL, as a senior scientist to join in the national mission to develop renewable energy. Noufi is involved in several professional societies, including the Materials Research Society (MRS), Electrochemical Society, American Chemical Society, and the Institute of Electrical and Electronics Engineers (IEEE). He has published more than 110 papers in journals and proceedings, and has received eight patents. $\mathrm{He}$ also is the recipient of several awards, including Midwest Research Institute's "H.M. Hubbard Award" in recognition of Outstanding Leadership and Initiative in Science and Technology Management (1993); Popular Science Magazine's Award for the Best of What is New in Science and Technology (1993); NREL's Technology Transfer Award (1994); and SERI's Outstanding Achievements Award (1982).

Fred Roozeboom is a principal scientist at Philips Research Laboratories in Eindhoven, The Netherlands, where since 1997 he leads a team working on the development of integrated high-value capacitors in macroporous silicon for application in rf decoupling. Roozeboom received his BSc (1972) and MSc (1976) degrees in chemistry at Utrecht State Uni- versity, and his PhD degree (1980) in chemical engineering at Twente University. He spent three years at ESSO (Exxon), working on zeolite catalyst synthesis, of which two years (1981-1982) were spent at Exxon R\&D Laboratories in Baton Rouge, Louisiana, and the remainder at Exxon Chemicals in Rotterdam. Since 1983 he has been working at Philips Research, first on metal organic chemical vapor deposition of III-V semiconductor lasers (until 1988), on integrated circuit metallization materials deposition and processing (until 1990), and on bulk ferrite and thin-film softmagnetic materials for magnetic recording. In 1996, he began working on molecularbeam epitaxy of ultrathin magnetic and "switchable mirror" hydride multilayers, until his present project on integrated decoupling capacitors started in 1997. In 1995, Roozeboom was director of a NATO Advanced Study Institute on Rapid Thermal and Integrated Processing. He has over 65 publications, holds several patents, and is the editor or co-editor of nine books on semiconductor processing. $\mathrm{He}$ is a member at large of the electronics division of the Electrochemical Society.

Susan Trolier-McKinstry is the Corning Faculty Fellow of Ceramic Science and Engineering and director of the W.M. Keck Smart Materials Integration Laboratory at The Pennsylvania State University (Penn State). Her main research interests include electroceramic thin films for actuator and dielectric applications, the development of texture in bulk ceramic piezoelectrics, and spectroscopic ellipsometry. She received her BS and MS degrees in 1987, and her PhD degree in 1992, all in ceramic science from Penn State. Trolier-McKinstry has held visiting appointments at Hitachi Central Research Laboratory, The Army Research 
Laboratory, and the Ecole Polytechnique Fédérale de Lausanne. She is a member of the American Ceramic Society, MRS, and IEEE. She is past president of Keramos, and the Ceramics Education Council, and Cochair of the committee revising the IEEE standard on ferroelectricity. She has served as an elected member of the IEEE Ultrasonics, Ferroelectrics, and Frequency Control Society advisory committee, and is currently chair of the IEEE UFFC Ferroelectrics group. She has previously coorganized MRS symposia in materials for smart systems and ferroelectric thin films.
Trolier-McKinstry is the recipient of the Robert Coble Award of the American Ceramic Society, the Wilson Award for Outstanding Teaching in the College of Earth and Mineral Sciences, the Materials Research Laboratory Outstanding Faculty Award, and an NSF CAREER grant. M[R]S 